その概要を発表した。

本器の構造は木製の椅子でその背面背中のあたる部分 と, これと直角の位置にあるフィルム支持具は被検者の 坐高に応じて上下に移動固定できるようになっている. かつフィルムはさらに各姿勢によって前後に移動できる ようにした，そして背中のあたる部分之前屈時の顔面を 支える部分には撮影時にX線透過の邪魔にならないよう に近時さかんに利用されている発泡スチール材を張りつ けた。

本器の使用法はいたって簡単で患者をまず椅子に深く 腰を後に引くようにして腰かけさせ後屈の場合は背中あ てを移動して適当な资勢でその後頭部を支える．前屈の 場合は椅子の前面についている顔面支持台に顔をもたせ かけるようにして固定. 中間位の場合は背中あての部分 を充分上方にあげてそれに背中と後頭部を垂直にあてれ ば事足りる．そしてその各姿勢応じてカセッテを上下 左右に動かして最良の位置に固定し撮影を実施すれば頸 椎側面写真が簡単にこれる。なおその撮影距離 FFD は $2 \mathrm{~m}$ ，リスなしでやっている.

\section{0. 幼児撮影についての試み}

東京厚生年金病院 放射線科

牛尼 晃弘・関 武夫 夫 的場 - 俊雄

幼児のX線撮影における体位の固定についてはすでに 種々研究応用されているが，いずれにしても泣き叫び， あばれる子供の充分な固定は難しい，放射線科に来る小 児はすでに各科において注射やその他の治療を受けてい るため警成心が強く，白农を芫ただけで泣き出すととも あり着农を脱すととになれば必死になって泣きだす，黒 く白くまたピカピカ光る大きなX線装置に用まれた中で 裸にされ冷たい板を身体につけられることは幼坚ならず とす良い気持のものではない，そとでわれわれは撮影室 内の霉囲気を変え幼児の気持を和らげ何等の抵抗むなく 撮影を完了すべく種々の方法を試みた。まず撮影室内を 明るくするために緑色のカーテンを張りビニール人形を 数個配置し，流行マンガを張り恰む幼児園の一室のごと き感じを出した。つぎに自動車型のカセッテ固定装置を 作り幼览をこれに乗せたまま胸部撮影を行なうようにし た。

\section{[方法]}

（1）受付空口にきた幼児を倩え付けの自動車に乗せ付 添の母親に押させ慣らす。

（2）折を見計ってそのまま撮影室内に送り込む。

(3) 母親にプロテクターを着けさせ幼児には玩具を与 え気嫝をとりながら脱衣させる。
（4）あらかじめ，定めておいた位置に自動車を固定す る.

（5）カセッテを装置し母親に体を支えさせる。

(6) 直にスイッチを人れて撮影を完了する。

以上幼児の気持を和らげ恐怖心を除く方法を講ずると とによって好結果を得た。

\section{1. 乳幼児に対する股関節精密検査の一方法}

大阪府立 身体障害者福祉センター

[目的]

○藤田 清三

整形外科領域において，乳幼児の股関節撮影は診断な らびに治療における精密検査の面で特に重要である。今 回演者は股関節正面像における下肢の内旋 ·正面・外旋 時の大腿骨頭と日蓋部の関係を分割 $\mathrm{X}$ 線像にて同一条件 下で並列に観察するため, 下記に示すような股関節精密 検査用撮影台を製作した。

[方法】

A) 構 造 (写真説明)

（1）撮影台中央に照射面積が六ツ切カセッテ縦位 $1 / 3$ 大 の照射寒を設置する。

（2）支持柱を作り，患者の骨船を固定する.

（3）力セッテを下 $\rightarrow$ 中 $\rightarrow$ 上逐次移動させ，下肢の内

旋・正面・外旋状態時を連続区分撮影を行なう。

B) 実 用 (写真説明)

(1) 膝部固定帯

（2）足部固定支持器

(3) 内外旋固定乙計測装置

（4）計測角度記録用回転フィルムマーク

（5）生殖腺防護板

[結果]

（1）照射面積が诙少のため，患者の被曝線量の軽減可 能

（2）介助者の散乱線被曝除去。

（3）骨盤固定が，確実であるため，一定肢位がとり易 《.

（4）1枚の写真上に精密検查の読影が可能かつ比較対照 し易い。

（5）撮影および現像の学力軽減と時間短縮.

（6）患者の支払負担の軽減.

\section{2. 角度可変斜臥位撮影台の試作 中間報}

済生会船橋病院放射線科

芝信男

船橋市役所衛生課

中村 精司 